\title{
STUDI EVALUASI PROSES PEMBELAJARAN PRAKARYA DAN KEWIRAUSAHAAN KELAS XII MIPA DI SMA NEGERI 1 SINGARAJA
}

\author{
K. Bayu Sukaharta ${ }^{1}$ N. Santiyadnya ${ }^{2}$, I. G. Nurhayata ${ }^{3}$ \\ 1,2Prodi Pendidikan Teknik Elektro, Universitas Pendidikan Ganesha, Singaraja \\ ${ }^{3}$ Prodi Teknik Elektronika, Universitas Pendidikan Ganesha, Singaraja \\ e-mail: arthabayu04@gmail.com , santiyadnya@undiksha.ac.id, gede.nurhayata@undiksha.ac.id
}

\begin{abstract}
Abstrak
Penelitian ini bertujuan mendeskripsikan kesesuaian perencanaan dan proses pembelajaran yang dilakukan oleh guru terhadap peraturan Permendikbud No. 22 Tahun 2016 dan mendeskripsikan kesesuaian pelaksanaan terhadap perencanaan pembelajaran yang telah dimiliki. Studi evaluasi penelitian ini meliputi perencanaan dan pelaksanaan proses pembelajaran prakarya dan kewirausahaan di SMA Negeri 1 Singaraja khususnya pada kelas XII MIPA. Sumber data pada penelitian ini adalah guru-guru prakarya dan kewirausahaan serta siswa-siswi yang dipilih menggunakan teknik purposive sampling. Teknik pengumpulan data yang digunakan adalah teknik wawancara, observasi partisipatif, studi dokumen, dan angket. Berdasarkan analisis data, didapatkan hasil penelitian antara lain: 1) variabel perencanaan pembelajaran pada masing-masing guru dapat dikatakan sesuai dengan Permendikbud No. 22 Tahun 2016; 2) model pembelajaran didalam pelaksanaan pembelajaran yang diterapkan oleh masing-masing guru berbeda namun masih didalam konteks pendekatan yang sama; 3) berdasarkan sudut pandang siswa memalui angket, pelaksanaan pembelajaran masing-masing guru mencapai kriteria baik.
\end{abstract}

Kata Kunci: Evaluasi, Proses Pembelajaran, Prakarya dan Kewirausahaan.

\section{Abstract}

This study aims to describe the suitability of planning and learning process conducted by the teacher to the rules Permendikbud No. 22 Year 2016 and describes the suitability of doubtgiven weight to the learning plan that has been held. The evaluation study of the study include the planning and implementation process of the craft and entrepreneurial learning in SMAN 1 Singaraja, especially in class XII Mathematics. Sources of data in this study were teachers craft and entrepreneurship as well as students were selected using purposive sampling. The data collection technique used is the technique of interview, observation partisipatif,study documents, and questionnaires. Based on data analysis, obtained results of the study are: 1) variable learning plan for each teacher can be said to correspond to Permendikbud No. 22, 2016; 2) learning model in the implementation of applied learning by each teacher is different but still within the context of the same approach; 3) based on the student's perspective based questionnaires, implementation of learning each teacher reaches criteria.

Keywords: Evaluation, Learning Process, Craft and Entrepreneurship.

\section{Pendahuluan}

Pendidikan merupakan proses pem- belajaran berkelanjutan yang berlangsung sepanjang hayat. Pendidikan sepanjang hayat memiliki makna bahwa manusia mempunyai peluang yang sama untuk memperoleh atau meningkatkan kecerdasan, wawasan, dan nilai hidup yang terwadahi dalam lingkup pendidikan. Sagala (2011: 2), menyatakan bahwa pendidikan adalah usaha sadar dan terencana untuk mewujudkan suasana belajar dan proses pembelajaran agar peserta didik secara aktif mengembangkan potensi dirinya untuk memiliki kekuatan spiritual keagamaan, pengendalian diri, kepribadian, kecerdasan, akhlak mulia, serta keterampilan yang diperlukan dirinya dalam masyarakat. Lebih lanjut Syaefudin (2008: 1), menegaskan bahwa "pendidikan merupakan upaya yangdapat mem-percepat pengembangan potensi manusia untuk mampu mengemban tugas yang dibebankan padanya, karena hanya manusia yang dapat dididik dan mendidik". Pada kurikulum 2013 terdapat pembelajaran baru, yaitu Prakarya dan Kewirausahaan. Pembelajaran ini lebih banyak menuntut skill dan keterampilan seseorang dalam berwirausaha. 
Pendidikan Prakarya dan Kewirausahaan diajarkan kepada semua siswa SMA, MA, dan SMK seperti tercantum dalam Kurikulum 2013. Mata Pelajaran Prakarya dan Kewirausahaan dapat digolongkan ke dalam pengetahuan transcience-knowledge, yaitu mengembang -kan pengetahuan dan melatih keterampilan kecakapan hidup berbasis seni dan teknologi berbasis ekonomi. Tujuan diberikannya mata pelajaran Prakarya dan Kewirausahaan, yaitu: 1) memfasilitasi peserta didik mampu berekspresi kreatif melalui keterampilan teknik berkarya ergonomis, teknologi dan ekonomis; 2) melatih keterampilan mencipta karya berbasis estetis, artistik, ekosistem dan teknologis; 3) melatih memanfaatkan media dan bahan berkarya seni dan teknologi melalui prinsip ergonomis, higienis, tepat-cekatcepat, ekosistemik dan metakognitif; 4) menghasilkan karya jadi maupun apresiatif yang siap dimanfaatkan dalam kehidupan, maupun bersifat wawasan dan landasan pengembangan apropriatif terhadap teknologi terbarukan dan teknologi kearifan lokal; 5) Menumbuhkembangkan jiwa wirausaha melalui melatih dan mengelola penciptaan karya (produksi), mengemas, dan usaha menjual berdasarkan prinsip ekonomis, ekosistemik dan ergonomis; 6) Melatih kemampuan berpikir kritis (Critical Thinking) dalam memahami hubungan sebab-akibat; menganalisis perbedaan dan persamaan, berpikir abstrak dan penyelesaian masalah (Problem Solving).

SMA Negeri 1 Singaraja merupakan salah satu sekolah menengah atas negeri di kota Singaraja yang menjalankan mata pelajaran prakarya dan kewirausahaan di semua jenjang pendidikannya mulai dari kelas X, kelas XI dan kelas XII. Mata pelajaran prakarya dan kewirausahaan ini banyak mengandung konten pembelajaran yang mengarahkan siswa untuk berfikir kreatif dan mampu mengembangkan pola fikir kreatif tersebut menjadi sebuah usaha pada bidang kewirausahaan. Namun berdasarkan pelaksanaannya, banyak siswa yang masih belum mengerti dan belum memahami manfaat dari mempelajari Prakarya dan Kewirausahaan. Proses pembelajaran didalam kelas memegang peranan penting didalam pelaksanaanya sehingga perlu adanya evaluasi untuk menemukan kesesuaian pada proses pembelajarannya. Dalam pelaksanaan proses belajar mengajar, seorang guru harus mampu membangun semangat dan motivasi belajar siswa dalam membangun pembelajaran yang efektif dan terpadu di kelas. Selain itu, guru juga harus memperhatikan kesesuaian perencanaan pembelajarannya terhadap pelaksanaan proses pembelajaran yang berlangsung agar tujuan pembelajaran tercapai dengan baik. Kemampuan menyusun perencanaan pembelajaran dan melaksanakan pembelajaran merupakan bagian dari kompetensi pedagogik guru yang harus dimiliki oleh guru untuk bisa melakukan pembelajaran yang mendidik sebagai persyaratan guru profesional.

Mata pelajaran prakarya dan kewirausahaan mengaharapkan siswa memiliki kemampuan berpikir kreatif yang tinggi, sehingga mudah untuk menciptakan sebuah peluang didalam kewirausahaan. Kemampuan berpikir kreatif yang rendah, mengakibatkan siswa kurang memahami suatu materi. Hal tersebut dapat mengakibatkan minat belajar siswa pun berkurang dan pemahaman menganai pentingnya pelajaran ini juga berkurang. Berkurangnya minat belajar dan pemahaman siswa pada mata pelajaran Prakarya dan Kewirausahaan tentu berdampak pada tingkat prestasi siswa dalam hasil belajarnya. Selain metode pembelajaran yang digunakan, ketepatan penggunaan startegi pembelajaran dan kelengkapan saranaprasarana penunjang proses pembelajaran juga harus dalam kondisi lengkap sehingga mampu menaikkan antusias belajar siswa.

Berdasarkan permasalahan yang ditemukan di SMA Negeri 1 Singaraja, maka perlu adanya studi evaluasi terhadap proses pembelajaran pada mata pelajaran Prakarya dan Kewirausahaan yang diharapkan dapat menjadi acuan pendidik didalam merencanakan dan melaksanakan proses pembelajaran. Salah satu alternatif yang dapat digunakan untuk mengatasi masalah tersebut adalah dengan melakukan evalusi kembali pada proses pembelajaran yang dilaksanakan dan apabila terdapat kekurangan didalam pelaksanaannya maka dapat dilakukan perbaikan dan pelengkapan pada proses pembelajarannya. Sehingga siswa mampu meningkatkan antusias belajar dan pemahamannya pada mata pelajaran Prakarya dan Kewirausahaan.

Sesuai dengan permasalahan yang telah dibahasmaka tujuan penelitian ini adalah mendeskripsikan kesesuaian perencanaanpembelajaran dan pelaksanaan pembelajaran yang 
dilakukan oleh guru dengan Permendikbud No. 22 Tahun 2016 mengenai standar proses pendidikan dasar dan menengah serta Mendeskripsikan hasil studi evaluasi proses pembelajaran Prakarya dan Kewirausahaan di kelas XII MIPA yang dilaksanakan oleh pendidik.

Suchman (1961) dalam Suharsimi (2009:1) mengatakan bahwa evaluasi sebagai sebuah proses menentukan hasil yang dicapai beberapa kegiatan yang direncanakan untuk mendukung tercapainya tujuan. Definisi lain dikemuka- kan oleh Worthen and Sanders (1973) dalam Suharsimi (2009: 1) yang menyatakan bahwa evaluasi adalah kegiatan mencari suatu yang berharga tentang sesuatu berupa bentuk informasi yang bermanfaat. Seorang ahli yang sangat terkenal dalam studi evaluasi bernama Stufflebeam (1971) dalam Suharsimi (2009: 2) menyatakan bahwa evaluasi merupakan proses penggambaran, pencarian, dan pemberian informasi yang sangat bermanfaat bagi pengambil keputusan dalam menentukan alternatif keputusan. Berdasarkan beberapa pendapat para ahli tersebut, maka dapat dikatakan bahwa studi evaluasi adalah suatu kegiatan yang bertujuan untuk mengumpulkan informasi tentang bekerjanya sesuatu, yang selanjutnya informasi tersebut digunakan untuk menentukan alternatif yang tepat dalam mengambil sebuah keputusan.

Pembelajaran adalah proses interaksi peserta didik dengan pendidik dan sumber belajar pada suatu lingkungan belajar. Pembelajaran merupakan bantuan yang diberikan pendidik agar dapat terjadi proses pemerolehan ilmu dan pengetahuan, penguasaan kemahiran dan tabiat, serta pembentukan sikap dan kepercayaan pada peserta didik. Dengan kata lain, pembelajaran adalah proses untuk membantu peserta didik agar dapat belajar dengan baik.Menurut Dimyati dan Mudjiono (Syaiful Sagala, 2011: 62) pembelajaran adalah kegiatan guru secara terprogram dalam desain instruksional, untuk membuat belajar secara aktif, yang menekankan pada penyediaan sumber belajar. Dalam Undang-Undang No. 20 Tahun 2003 Tentang Sistem Pendidikan Nasional pasal 1 ayat 20 dinyatakan bahwa Pembelajaran adalah Proses interaksi peserta didik dengan pendidik dan sumber belajar pada suatu lingkungan belajar. Konsep pembelajaran menurut Corey (Syaiful Sagala, 2011:

61) adalah suatu proses dimana lingkungan seseorang secara disengaja dikelola untuk memungkinkan ia turut serta dalam tingkah laku tertentu dalam kondisi-kondisi khusus atau menghasilkan respons terhadap situasi tertentu, pembelajaran merupakan subset khusus dari pendidikan. Pembelajaran mengandung arti setiap kegiatan yang dirancang untuk membantu seseorang mempelajari suatu kemampuan dan nilai yang baru.Tujuan pembelajaran pada dasarnya merupakan harapan, yaitu apa yang diharapkan dari siswa sebagai hasil belajar. Menurut $\mathrm{H}$. Daryanto (2005: 58) tujuan pembelajaran adalah tujuan yang menggambarkan pengetahuan, kemampu- an, keterampilan, dan sikap yang harus dimiliki siswa sebagai akibat dari hasil pembelajaran yang dinyatakan dalam bentuk tingkah laku yang dapat diamati dan diukur. Tujuan pembelajaran memang perlu dirumuskan dengan jelas, karena perumusan tujuan yang jelas dapat digunakan sebagai tolak ukur keberhasilandari proses pembelajaran itu sendiri. Tujuan pembelajaran juga harus dirumuskan secara lengkap agar tidak menimbulkan penafsiran yang bermacam-macam.

Perencanaan pembelajaran merupa -kan salah satu faktor yang menentukan keberhasilan pelaksanaan pembelajaran. Perencanaan pembelajaran dilakukan secara terstruktur dan berkualitas, sehingga menghasilkan pelaksanaan pembelajaran yang lebih baik. Berdasarkan hal tersebut, RPP yang disusun guru harus lengkap dan sistematis, sesuai dengan struktur yang telah ditetapkan pada kurikulum 2013. RPP memiliki dua fungsi, yaitu fungsi perencanaan dan fungsi pelaksanaan. Fungsi perencanaan dari RPP terkait dengan rencana pelaksanaan pembelajaran yang berfungsi membantu guru agar lebih siap dalam melakukan kegiatan pembelajar -an, sedangkan fungsi pelaksanaan dari RPP, untuk mengefektif- kan proses pembelajaran sesuai dengan apa yang telah direncanakan. Oleh karena itu, hendaknya guru memahami komponen-komponen RPP dan melaksanakan kegiatan pembelajaran berdasarkan RPP yang telah dirancang (Giartha, 2015).Pengembangan RPP dilakukan sebelum awal semester atau awal tahun pelajaran dimulai. Namun RPP tersebut perlu diperbaharui sebelum pembelajaran dilaksanakan. Pengembangan RPP dapat dilakukan oleh guru secara mandiri atau berkelompok disekolah yang dikoordinasi difasilitasi, dan disupervisi oleh kepala sekolah. Pengembangan RPP juga 
dapat dilakukan oleh guru secara berkelompok antar sekolah atau antar wilayah yang dikoordinasi, difasilitasi, dan disupervisi oleh dinas pendidikan atau kantor kementerian agama setempat (Angga, 2016).

Prakarya dan kewirausahaan merupakan sebuah mata pelajaran yang terdiri dari dua suku kata yaitu prakarya dan wirausaha. Prakarya merupakan hasil kerja berupa keterampilan, hastakarya, kerajinan yang penggunaan bahannya tersedia secara umum. Prakarya mempunyai peranan penting dalam pengembangan kreatifitas menjadi sebuah inovasi baru. Kewirausahaan merupakan proses kemanusiaan yang berkaitan dengan adanya kreativitas serta inovasi dalam memahami suatu peluang, mengorganisasi -kan sumber - sumber serta mampu mengelola sehingga peluang tersebut dapat terealisasi dengan baik. Sehingga prakarya dan kewirausahaan dapat diartikan sebagai ilmu pengertahuan yang berbasis keterampila, kerajinan dan hastakarya yang bersifat inovatif dan mampu menjadikan hasil karya tersebut menjadi sebuah peluang, mengorganisasi-kan dan mampu mengelola inovasi hasil karya dan keterampilan didalam berwirausaha. Mata Pelajaran Prakarya dan Kewirausahaan dapat digolongkan ke dalam pengetahuan transcience-knowledge, yaitu mengembang -kan pengetahuan dan melatih keterampilan kecakapan hidup berbasis seni dan teknologi berbasis ekonomis. Pembelajaran ini berawal dengan melatih kemampuan ekspresikreatif untuk menuangkan ide dan gagasan agar menyenangkan orang lain, dan dirasionalisasikan secara teknologis sehingga keterampilan tersebut bermuara apresiasi teknologi terbarukan, hasil ergonomis dan aplikatif dalam memanfaatkan lingkungan sekitar dengan memperhatikan dampak ekosistem, manajemen dan ekonomis. Suatu Keterampilan akan menghasilkan sebuah karya yang menyenangkan bagi dirinya maupun orang lain serta mempunyai nilai kemanfaatan, sehingga pelatihan berkarya harus dimulai dengan memahami estetika (keindahan) sebagai dasar penciptaan sebuah karya. Dalam rangkaian menemukan karya yang bermanfaat maka dilatihkan mencipta, memproduksi dan memelihara karya yang ada kemudian memperoleh nilai kebaruan (novelty) sehingga bermanfaat untuk kehidupan selanjutnya.

\section{Metode}

Penelitian ini merupakan penelitian kualitatif studi evaluasi. Karena peneliti ini mengamati proses pembelajaran yang dilaksanakan pendidik secara kualitatif. Model studi evaluasi yang digunakan adalah evaluasi formatif-sumatif.Evaluasi formatif dilaksanakan pada saat implementasi program sedang berjalan. Evaluasi formatif adalah penggunaan instrumen variabel selama program yang masih berlangsung, agar peneliti dan sumber penelitian memperoleh informasi (feedback) mengenai variabel yang ingin atau telah dicapai. Tujuan evaluasi ini adalah mengetahui seberapa jauh program yang dirancang dapat dilaksanakan dan dapat mengetahui hambatan-hambatan didalam pelaksanaannya.

Evaluasi sumatif adalah evaluasi yang dilakukan pada awal atau akhir dalam satu satuan waktu yang didalamnya mencakup lebih dari satu pokok variabel bahasan. Evaluasi ini dimaksudkan untuk mengetahui sejauhmana kesiapan dan hasil perkembangan objek penelitian yang telah melakukan atau dilaksanakannya suatu program (Suharsimi,2009).Penelitian ini bertujuan untuk mengetahui kesesuaian proses pembelajaran yang dilaksanakan pendidik atau guru yang sedang berlangsung terhadap peraturan Kemendikbud 2016 pada mata pelajaran prakarya dan kewirausahaan kelas XII MIPA di SMA Negeri 1 Singaraja.

Sumber data didalam penelitian ini dilakukan dengan teknik purposive sampling. Purposive sampling adalah suatu teknik pengumpulan sampel penelitian yang dipilih berdasarkan pertimbangan dan tujuan tertentu, dalam rangka ketepatan dan kecukupan informasi yang dibutuhkan (Sugiono, 2012). Penentuan sumber data penelitian ini juga berdasarkan kriteria sumber data penelitian menurut Sanafiah Faisal (dalam Sugiyono, 2012), yaitu 1) mereka yang menguasai atau memahami sesuatu melalui proses enkulturasi, sehingga sesuatu itu bukan hanya sekadar diketahui, namun juga dihayati; 2) mereka yang tergolong masih sedang berkecimpung atau terlibat pada kegiatan yang tengah diteliti. 3) mereka yang mempunyai waktu memadai untuk dimintai informasi; 4) mereka yang tidak cenderung menyampaikan informasi hasil kemasannya sendiri; 5) mereka yang mulanya 
cukup asing dengan peneliti, sehingga akan lebih menggairahkan untuk dijadikan narasumber.Data penelitian yang akan digunakan oleh peneliti didalam penelitian ini antara lain : 1) data hasil wawancara terhadap informan; 2) data hasil telaah semua perencanaan pembelajaran berupa RPP yang digunakan oleh guru untuk kelas XII MIPA tahun ajaran $2017 / 2018$; 3) data hasil observasi proses pembelajaran didalam kelas yang dilaksanakan oleh pendidik bersangkutan; 4) data hasil pengisian angket yang dilakukan siswa selama mengikuti proses pembelajaran prakarya dan kewirausahaan. Data - data tersebut tentu berkaitan dengan bagaimana proses dan persiapan guru atau pendidik didalam melaksanakan pembelajaran prakarya dan kewirausahaan.

Menurut Sugiyono (2012: 193-194), teknik atau metode pengumpulan data adalah cara-cara yang digunakan untuk menghimpun serangkaian data dengan prinsip-prinsip dan alat-alat tertentu. Ketepatan penggunaan metode pengumpulan data tergantung pada keperluan dan ketepatannya, yakni berdasarkan jenis data yang akan dikumpulkan. Jenis data dalam penelitian ini berupa deskripsi proses pembelajaran Prakarya dan Kewirausahaan, maka teknik atau metode yang digunakan didalam penelitian ini adalah wawancara mendalam (depth interview), observasi partisipatif, dokumentasi atau studi dokumen dan pemberian angket.

Menurut Aziz Firdaus (2012: 37-38), interview atau wawancara dilakukan secara langsung terhadap seseorang dengan menggunakan model "probing" oleh seseorang pewawancara. Tujuan dari wawancara dept interview ini adalah untuk mengetahui berbagai hal yang belum terungkap oleh responden seperti; motivasi, kepercayaan, prilaku, dan perasaan terhadap suatu topik tertentu sehingga diperoleh suatu data yang dapat dianalisis. Wawancara mendalam (depth interview) atau sering dikenal dengan istilah wawancara semiterstruktur, dimana peneliti menyiapkan instrument penelitian berupa pertanyaanpertanyaan tertulis, namun dalam pelaksanaannya, konteks wawancara dapat berkembang diluar rubrik wawancara.Observasi partisitaif menurut Aziz (2012: 39) adalah suatu teknik penelitian yang bertujuan memperoleh suatu data melalui pengamatan langsung terhadap suatu objek pada periode tertentu. Jenis obsevasi partisipatif yang digunakan dalam penelitian ini adalah obsevasi partisipatif terbuka, dimana dalam mengumpulkan data, peneliti melakukan observasi partisipatif pada semua aktivitas sumber data, namun hanya beberapa kegiatan yang terkait dengan fokus penelitian. Selama obsevasi berlangsung, peneliti melakukan kegiatan pencatatan, perekaman, pendeskripsian dan penginterpretasikan data yang berkaitan dengan fokus penelitian.

Menurut Sugioyo (2012: 198-199), Studi dokumen digunakan sebagai pelengkap dari data yang diperoleh dari metode wawancara mendalam dan observasi partisipatif. Data penelitian dari hasil wawancara dan observasi akan lebih dapat dipercaya, jika didukung oleh suatu dokumen tentang data tersebut. Teknik ini bertujuan memberikan bukti keabsahan suatu data atau dokumen yang telah didokumentasikan selama penelitian dilaksanakan. Didalam teknik studi dokumen, peneliti melakukan telaah atau pemeriksaan kesesuaian isi terhadap dokumen perencanaan pembelajaran yang telah dibuat atau dimiliki oleh narasumber.Penelitian ini menggunakan instrument angket dengan model Close Ended Questionnaire dalam bentuk Close Ended Questionnaire Cheklist. Menurut Aziz (2012: 67-68), model Close Ended Questionnaire memungkinkan peneliti untuk melakukan proses tabulasi, dan analisis secara lebih cepat, serta dalam penyusunannya dapat menggunakan alat bantu seperti komputer sehingga dapat menghemat dari sisi waktu didalam proses pembuatannya. Bagi responden, bentuk model ini akan membutuhkan waktu yang jauh lebih singkat dibandingkan dengan model lainnya. Didalam penelitian ini, pemberian angket bertujuan untuk mendeskripsikan hasil temuan-temuan yang didapatkan oleh peneliti didalam proses pembelajaran yang dilaksanakan oleh narasumber. Hasil pemberian angket ini adalah hasil pengamatan atau keterlibatan sesorang didalam proses pembelajan yang dilaksanakan oleh narasumber didalam penelitian ini.

Analisis data kualitatif adalah upaya yang dilakukan dengan jalan bekerja dengan data, mengorganisasikan data, memilah menjadi satuan yang dapat dikelola, mensintesiskannya, mencari dan menemukan pola, menemukan apa yang penting dan apa yang dipelajari, dan memutuskan apa yang dapat diceritakan kepada orang lain. Keberadaan data yang 
didapatkan oleh peneliti di lapangan mengharuskan adanya analisis data secara sistematis, supaya data yang didapatkan memadai, akurat, dan dapat mengungkap keadaan sebenarnya kondisi di lapangan. Menurut Bungin (dalam Zaenab, 2015: 63), Analisis data dalam penelitian kualitatif berlangsung secara bertahap terhadap proses pengumpulan data. Diantaranya adalah melalui tiga tahap, yaitu reduksi data, penyajian data, dan verifikasi.

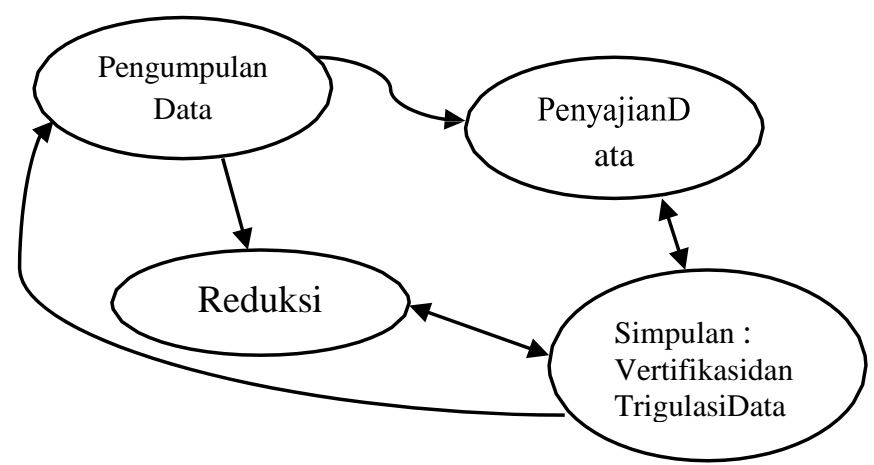

Gambar 1. Analisa Penelitian Kualitatif

Adapun langkah-langkah kerja yang dilakukan pada tahap reduksi data, sebagai berikut. Data pada catatan lapangan disusun kembali dan dicocokkan dengan data yang ada pada transkrip hasil rekaman sehingga menggambarkan kegiatan pembelajaran secara keseluruhan dan utuh.

Menurut Miles dan Huberman (dalam Sugiyono, 2012: 344), reduksi data merupakan proses berfikir sensitif yang memerlukan kecerdasan, keluasan dan kedalaman wawasan yang tinggi.Menurut Wiyono (dalam Zaenab, 2015: 65), penyajian data merupakan perakitan informasi yang terorganisir yang memungkinkan penarikan kesimpulan.Menurut Zaenab (2015: 66), penarikan kesimpulan adalah bagian akhir kegiatan analisis data. Proses ini dapat berupa pencarian pola-pola penjelasan, konfigurasi, sebab-akibat dan proposisi dari proses analisis penelitian. Dengan demikian dapat dikatakan bahwa, reduksi data, penyajian data dan vertifikasi data adalah serangkaian proses analisa data yang tidak dapat dipisahkan.

\section{Hasil dan Pembahasan}

Berdasarkan hasil wawancara, observasi partisipatif, dan penyebaran angket terhadap pelaksanaan pembelajaran yang dilaksanakan oleh guru $A$ dan guru $B$ dapat dinyatakan bahwa guru $A$ sudah mengikuti tahapan perencanaan pembelajaran khususnya RPP. Guru $A$ mampu bertindak sesuai layaknya rancangan teoritis pada RPP namun konteks pembelajarannya tetap dan tidak akan jauh dari perencanaan pembelajaran yang telah disusun. Sedangkan guru B, sudah mengikuti kegiatan pembelajaran yang direncanakan dengan baik namun penggunaan model dan metode pembelajaran yang digunakan sangat berbeda dari perencanaan pembelajaran- nya. Guru B belum mampu bertindak sesuai dengan rancangan teoritis pada RPP namun konteks pembelajarannya masih mengikuti prosedur kegiatan pembelajaran dengan menggunakan model dan metode pembelajaran yang berbeda.

Menurut Permendikbud No. 22 Tahun 2016 Bab II mengenai karakteristik pembelajaran yang mengatur tentang penggunaan pendekatan dan model pembelajaran, guru A dan guru B telah menggunakan pendekatan yang di atur pada Permendikbud tersebut. Guru A menggunakan pendekatan Saintifik dengan model pembelajaran Discovery Learning dan guru B menggunakan pendekatan Saintifik dengan model pembelajaran Project Based Learning. Kedua pendekatan yang dilaksanakan oleh kedua guru sudah sesuai dengan Permendikbud yang mengatur proses pembelajaran dengan kurikulum 2013.Didalam Permendikbud No. 22 Tahun 2016 Bab IV point 2 mengenai pelaksanaan pembelajaran, terdapat tiga kegiatan yang merupakan implementasi dari penerapan RPP. Kegiatan tersebut adalah kegiatan pendahuluan, kegiatan inti, dan kegiatan penutup. Berdasarkan hasil penelitian, kedua guru sudah menerapkan ketiga kegiatan pembelajaran. Namun, masih ditemukan kekurangan didalam pelaksana- ankegiatan tersebut. Kekurangan ini ditemukan 
pada kegiatan pembukaan dan penutup. Pada kegiatan pembuka, guru A belum mampu memberikan motivasi sebelum memulai pembelajaran dan guru B belum mampu memberikan motivasi dan menjelaskan cangkupan dari materi yang akan diberikan. Pada kegiatan penutup, guru A sudah menerapkan kegiatan yang diatur oleh Permendikbud dan guru B belum mampu menerapkan kegiatan yang diatur oleh Permendikbud seperti memberikan kesimpulan, memberikan umpan balik atau tanya jawab, dan memberikan tugas mandiri. Guru B hanya menyampaikan kegiatan yang akan dilaksanakan pada pertemuan berikutnya. Secara garis besar, kedua guru sudah mampu menerapkan ketiga kegiatan pembelajaran yang diatur pada Permendikbud No. 22 Tahun 2016 Bab IV point 2 mengenai pelaksanaan pem- belajaran dengan baik.

Berdasarkan hasil studi dokumen dan observasi dokumen, rencanan pelaksanaan pembelajaran yang dimiliki oleh kedua guru sudah sesuai dengan Permendikbud No. 22 Tahun 2016 Bab III point 2 mengenai perencanaan pem- belajaran khususnya komponen- komponen penyusunan RPP. Komponen-komponen tersebut adalah identitas sekolah, identitas mata pelajaran, kelas, materi pokok, alokasi waktu, tujuan pembelajaran, kompetensi dasar, kompetensi inti, materi pembelajaran, metode pembelajaran, media pembelajaran, sumber belajar, langkah-langkah pembelajaran, dan penilaian. Seluruh komponen tersebut tertera pada kedua RPP yang dimiliki kedua guru sehingga dapat dikatakan bahwa kedua RPP sudah sesuai dengan Permendikbud No. 22 Tahun 2016 yang dikeluarkan oleh Kemendikbud.

Didalam Permendikbud No. 22 Tahun 2016 Bab III, penyusunan RPP sebaiknya dilakukan secara mandiri oleh masing-masing pendidik dengan mengacu kepada kompetensi dasar (KD) pada silabus pem- belajaran yang sudah ada. Berdasarkan hasil wawancara dan observasi dokumen, guru A sudah menerapkan prinsip penyusunan RPP yang diatur oleh Permendikbud tersebut dengan menyusun RPP secara mandiri. Sedangkan guru B, meminta ketua MGMP untuk menyusun RRP yang dimilikinya sehingga guru $B$ dapat dikatakan belum mampu menerapkan aturan yang diatur oleh Permendikbud No. 22 Tahun 2016 Bab III tentang prinsip penyusunan RPP.Masing-masing proses pembelajaran yang dilaksanakan oleh masing-masing guru dapat diterima dengan baik oleh siswa. Hal ini ditunjukkan dengan bukti hasil penyebaran angket yang memiliki hasil reliabilitas yang berbeda hanya 0.005 dan samasama termasuk didalam kategori derajat reliabilitas tinggi sehingga respon siswa pada proses pembelajaran masing-masing guru berkategori baik.

Fungsi siswa sebagai renponden didalam penyebaran angket ini adalah sebagai pertimbangan peneliti yang dilihat dari sudut pandang berbeda. Hasil angket ini menjadi pembanding hasil observasi partisipatif yang dilakukan oleh peneliti. Hasil ini akan menjadi hasil perbandingan yang diamati dan dialami peneliti selama observasi terhadap apa yang diamati dan dialami oleh siswa. Hasil perbandingan ini akan menjadi titik acuan peneliti yang dilihat dari dua sudut pandang yang berbeda guna sebagai pelengkap didalam tringulasi penelitian kualitatif ini.Secara garis besar, proses pembelajaran yang dilaksanakan oleh kedua guru masuk kedalam kategori baik. Hal ini dilihat berdasarkan kesesuaian perencanaan pembelajaran dan kesesuian pelaksanaan pembelajaran yang sudah sesuai dengan Permendikbud No. 22 Tahun 2016. Berdasarkan perhitungan penilaian proses pembelajaran, guru A mendapatkan jumlah persentase kesesuaian sebesar $74,3 \%$ dan guru B mendapatkan jumlah persentase kesesuaian sebesar $69,6 \%$. Hasil kedua penilaian kesesuaian tersebut masuk kedalam kategori atau kriteria baik. Selain hasil kesesuaian variable penelitian tersebut, proses pembelajaran yang dilakukan oleh kedua guru masuk kedalam kategori baik didukung berdasarkan hasil uji reliabilitas angket yang disebar ke masing-masing kelas belajar kedua guru. Uji reliabilitas angket kedua guru tersebut menunjukan hasil derajat reliabilitas tinggi atau baik berdasarkan kriteria reliabilitas Guilford.

\section{KESIMPULAN DAN SARAN}

Penyusunan perencanaan pem- belajaran berupa RPP yang disusun atau dimiliki oleh kedua guru secara garis besar sudah sesuai dengan permendikbud No. 22 Tahun 2016 Bab 
III bagian 2 yang mengatur komponen-komponen atau variable didalam penyusunan sebuah RPP.Pelaksanaan pembelajaran yang dilaksanakan oleh kedua guru meliputi tiga bagian kegiatan pembelajaran, yaitu pendahuluan, kegiatan inti, dan penutup. Hal ini sudah sejalan dengan peraturan Permendikbud No. 22 Tahun 2016 Bab IV bagian B yang mengatur pelaksanaan pembelajaran yang berimplementasi pada perencanaan pembelajaran yang telah direncanakan.3) Berdasarkan hasil studi evaluasi yang dilakukan oleh peneliti, Pelaksanaan proses pembelajaran yang dilaksanakan oleh guru $A$ dan guru $B$ dapat dikatakan bahwa guru A sudah mengikuti tahapan perencanaan pembelajaran khususnya RPP dengan baik. Sedangkan guru B, sudah mengikuti kegiatan pembelajaran yang direncanakan dengan baik namun penggunaan model dan metode pembelajaran yang digunakan sangat berbeda dari perencanaan pembelajarannya.

Menurut hasil studi dokumen, kedua guru sudah mencakup seluruh variable atau komponen penyusunan RPP sudah sesuai dengan Permendikbud No.22 Tahun 2016 Bab III point 2 Namun terdapat kekurangan pada kedua RPP yaitu pada indikator pencapaian kompetensi (IPK). Indikator tersebut antara lain, tidak mencantumkan KD dari KI-1 (aspek sikap spiritual) dan KD dari KI-2 (aspek sikap sosial) yang relevan dengan KD dari KI-3; dan tidak memuat indikator dimensi sikap yang diturunkan dari KI-1 (aspek sikap spiritual) dan KI2 (aspek sikap sosia). Hasil penyebaran angket mengenai pandangan siswa terhadap proses pembelajaran yang dilaksanakan oleh kedua guru, didapatkan hasil validitas guru A sebesar 0.571 dan hasil realibiltas sebesar 0.748 . Sedangkan untuk guru B, didapatkan hasil validitas sebesar 0.541 dan hasil realibilitas sebesar 0.743 . Hasil tersebut menunjukan bawah proses pembelajaran yang dilaksanakan oleh kedua guru masuk kategori baik. Berdasarkan penerapan seluruh instrumen penelitian, proses pembelajaran yang dilaksanakan oleh kedua guru masuk kedalam kategori atau kriteria baik dengan hasil persentase $74,3 \%$ dan $69,6 \%$.

Guru diharapkan lebih cermat dalam menyusun RPP dan selalu menyesuaikan dengan peraturan perundang-undangan Kurikulum 2013 yang berlaku agar tidak ada satupun komponen RPP yang terlewatkan. Guru juga diharapkan mengukuti pelatihan- pelatihan penyusunan perencanaan pembelajaran yang dilaksanakan oleh pihak sekolah maupun oleh pihak dinas terkait sehingga meminimalisir terjadinya perbedaan persepsi antar guru didalam penyusunan RPP dan guru diharapkan mampu meng- implementasikan perencanaan pembelajaran yang sudah disiapkan pada pelaksanaan proses pembelajarannya. Sehingga pelaksanaan pembelajaran yang diberlakukan sesuai denga peraturan undan-undang kurikulum 2013 pada Permendikbud No.22 Tahun 2016 Bab II yang mengatur pendekatan proses pembelajaran pada kurukulum 2013 dan Bab IV bagian B yang mengatur pelaksanaan pembelajaran berimplementasi pada perencanaan pem- belajaran.

\section{DAFTAR PUSTAKA}

Arikunto, Suharsimi., dan Safruddin, Cepi. 2009. Evaluasi Program Pendidikan (Edisi 2). Jakarta: PT. Bumi Aksara.

Candiasa, I Made. 2011. Pengujian Instrumen Penelitian Disertai AplikasilTEMAN dan BIGSTEPS. Singaraja: Undiksha Press.

Daryanto, H. 2005. Evaluasi Pendidikan. Jakarta: Rineka Cipta.

Firdaus, M. Aziz. 2012. Metode Penelitian. Tanggerang Selatan: Jelajah Nusa.

Giartha, I. N. K. 2015. Kajian Pengelolaan Pembelajaran Fisika Berbasis Kurikulum 2013 Di SMA Negeri 1 Ubud. Singaraja: Universitas Pendidikan Ganesha.

Kemendikbud. 2016. Lampiran Permendikbud Nomor 22 Tahun 2016 tentang Standar Penilaian Pendidikan. Diakses pada 15 Agustus 2017. 
Kunandar. 2013. Penilaian Autentik (Penilaian Hasil Belajar Peserta DidikBerdasarkan Kurikulum 2013). Jakarta: PT Rajagrafindo Persada.

Rismanika, Putu Angga. 2016. Peran Guru Dalam Pengelolaan Pembelajaran Prakarya Dan Kewirausahaan Sebagai Implementasi Kurikulum 2013 Di SMAN 4 Singaraja (tidak diterbitkan). Singaraja: Universitas Pendidikan Ganesha.

Suyono dan Hariyanto. 2014. Belajar dan Pembelajaran: Teori dan Konsep Dasar. Bandung: PT. Remaja Rosda Karya.

Saefudin, Sa'ud Udin. 2008. Inovasi Pendidikan. Bandung: Alfabeta

Sagala, Syaiful. 2011. Konsep dan Makna Pembelajaran (Problematika Belajar dan Mengajar). Bandung: Alfabeta.

Sugiyono. 2012. Metode Penelitian Pendidikan (Pendekatan Kuatitatif, Kualitatif dan R\&D). Bandung: Alfabeta.

Uno, Hamzah B. 2008. Profesi Kependidikan. Jakarta: PT.Bumi Aksara.

Zaenab, Siti. 2015. Metodologi Penelitian Pendidikan Kualitatif. Malang: Selaras. 